\title{
Study of domestic coal-based dimethyl ether (DME) utilization to reduce LPG import
}

\author{
Annisa Muliahati ${ }^{1,}$, Eva Fathul Karamah ${ }^{2}$, and Ika Kaifiah ${ }^{3}$ \\ ${ }^{1}$ Gas Management, Chemical Engineering Indonesia University, Depok, Indonesia \\ ${ }^{2}$ Chemical Engineering, Indonesia University, Depok, Indonesia \\ ${ }^{3}$ PPPMGB Lemigas, South Jakarta, Indonesia
}

\begin{abstract}
.
This study evaluates the utilization of domestic coal-based dimethyl ether (DME) to substitute $15 \%$ of the total household sector demand of LPG import projected to year 2040 and the impact to the saving of state budget. Maximum LPG-DME blending in this study is $85 \%-15 \%$ weight. DME-LPG mixture price at depot will be calculated based on DME FOB price at production plant, shipping cost, mixing and handling cost. The result of the research shows that DME-LPG mixture price and the import LPG price at each depot are $391 \mathrm{USD} / \mathrm{MT}$ and $620 \mathrm{USD} / \mathrm{MT}$ at Depot Tanjung Priok, $390 \mathrm{USD} / \mathrm{MT}$ and $620 \mathrm{USD} / \mathrm{MT}$ at Depot Eretan, 396 USD/MT and 622 USD/MT at Depot Tanjung Perak, 397 USD/MT and 622 USD/MT at Depot Gresik, and 401 USD/MT and 624 USD/MT at Depot Semarang. The substitution of LPG import with domestic coal-based DME results the saving of state budget about 388 million USD (IDR 5,332 billion). It concludes that the utilization of domestic coal-based DME is economically feasible to reduce the import of LPG per metric ton (MT), obtain the saving for state budget, and help the government to decrease the dependency of import LPG to maintain the national energy security.
\end{abstract}

\section{Introduction}

Since 2015, LPG demand in Indonesia reached 7.5 million TOE (tonne of oil equivalent) meanwhile the existing national production only 2.9 million TOE. Therefore, in 2016 the LPG import reached $67 \%$ of total national demand and the amount of state budget about 2,647 million USD (IDR 36,367 billion). It is necessary to find alternative energy that can help the government to reduce the burden of LPG import that impact on state budget saving. One of the alternative energy to substitute LPG import is Dimethyl Ether (DME).

DME has similar characteristics to LPG. DME can be produced from coal, natural gas, and biomass. However, the production of DME from coal provides the lowest production cost [1]. Indonesia as the second highest coal exporter country in the world contributes $28 \%$ of world's need [4]. Ironically, from the total national coal production in 2015 , more than $75 \%$ was exported to other countries [8]. In fact, with total reserves of domestic coal per year 32.3 billion metric tons (MT) and the average coal demand growth of $6 \%$ per year, the reserves can be produced up to 40 years. So, the DME production from domestic coal can be sustained. Therefore, this study will evaluate the feasibility of coalbased DME utilization to reduce LPG import in Indonesia. This utilization will not only optimize the use of domestic coal but also overcome the growing LPG demand.

\footnotetext{
* Corresponding author: annisamuliahati@gmail.com
}

\subsection{Characteristic of DME}

The largest market of DME is as blend fuel with LPG for the residential cooking and heating, particularly in China [3]. This is related to the fact that DME can be blended with LPG up to $15 \%$ weight and would not require any modification either in the existing distribution infrastructure or in the users' appliances [7].

From some studies it is known that DME is an alternative fuel that can be used as a mixture for other fuels or even as pure DME [2]. Here is a comparison between DME and LPG in Table 1.

Table 1. Physical Properties \& Characteristics of DME Compare to Other Fuels

\begin{tabular}{|c|c|c|}
\hline Characteristics & DME & LPG \\
\hline Formula & CH3OCH3 & C3H8 \\
\hline Boiling Point $\left({ }^{\circ} \mathrm{C}\right)$ & -25 & -42 \\
\hline Liquid Density $(\mathrm{kg} / \mathrm{m} 3)$ & 0.66 & 0.49 \\
\hline Viscosity, $40^{\circ} \mathrm{C}(\mathrm{cP})$ & 0.18 & 0.1 \\
\hline Cetane Number & $55-60$ & 5 \\
\hline Auto Ignition Temp. $\left({ }^{\circ} \mathrm{C}\right)$ & 235 & 470 \\
\hline Lower Heating Value $(\mathrm{MJ} / \mathrm{kg})$ & 28.8 & 46 \\
\hline
\end{tabular}

Based on the table, it can be seen that DME has similar characteristics to LPG but has a lower heating value than LPG. In this study will be evaluated the feasibility of DME-LPG as a mixture to substitute LPG import. 


\subsection{DME-LPG Mixture}

The research that assess the amount of fuel consumption need for the burner test, has been done by PPPTMGB Lemigas by modifying burner which is generally used in household sector. It is given the same burning load and the result showed that the average amount of LPG consumption about $0.24 \mathrm{~kg}$ while the average amount of DME consumption about $0.35 \mathrm{~kg}$ [1]. Therefore, the equivalence of DME and LPG fuels from the test results on the modified burner is 1.5 which means that $1 \mathrm{~kg}$ of LPG is equivalent to $1.5 \mathrm{~kg}$ DME. This value becomes a reference in the economic calculation analysis.

Meanwhile, the specification for DME as household and industrial fuel in Indonesia is regulated in Decree of The Director General of Oil and Gas Number 990.K/10/DJM.S/2013, as follows in Table 2.

Table 2. The Specification for DME as Household and Industrial Fuel in Indonesia

\begin{tabular}{|c|c|c|c|c|}
\hline \multirow{2}{*}{ Characteristics } & \multirow{2}{*}{ Units } & \multicolumn{2}{|c|}{ Limitation } & \multirow{2}{*}{ Test Method ASTM } \\
\hline & & Min & Max & \\
\hline Specific Gravity $60 / 60 \mathrm{oF}$ & & \multicolumn{2}{|c|}{ Reported } & D 1657/ D2598 \\
\hline Vapour Pressure @100 oF & psig & & 145 & $\mathrm{D} 1267$ \\
\hline Weathering Test @36oF & $\%$ vol & 95 & & D 1837 \\
\hline Copper Corrosion & \multicolumn{2}{|c|}{1 hour $/ 100 \mathrm{oF}$} & No.1 & D 1838 \\
\hline Total Sulphur & \multicolumn{2}{|c|}{ Grains/100 cuft } & 15 & D 2784 \\
\hline Water Content & & \multicolumn{2}{|c|}{ No Free Water } & Visual \\
\hline $\begin{array}{l}\text { Composition } \\
\text { - } \mathrm{CH} 3 \mathrm{OCH} 3 \\
\text { - } \mathrm{CH} 3 \mathrm{OH} \\
\text { - Others (light ends) }\end{array}$ & $\%$ vol & 100 & $\begin{array}{l}0.4 \\
0.1\end{array}$ & D 2163 \\
\hline Ethyl atau Butyl Mercaptan & \multicolumn{2}{|c|}{$\mathrm{ml} / 1000 \mathrm{AG}$} & 50 & Calculated \\
\hline
\end{tabular}

\subsection{DME Demand for Household Sector in 2040}

The limitation of this study is the amount of DME that will be evaluated to substitute LPG imports is $15 \%$ of the total imported LPG demand in 2040. Because the maximum amount of DME that can be blended with LPG is only $15 \%$ weight ( $85 \%$ weight LPG) without any modification to the existing household sectors' facilities. The LPG demand forecasting in 2040 is calculated based on Indonesia Energy Outlook (IEO) 2016 data in business as usual (BAU) scenario with increasing LPG demand $2 \%$ per year. LPG import demand forecasting in 2040 is $8,442,253$ MT. Based on this study limitation, therefore the amount of DME demand in 2040 is $1,899,507$ MT. Then it will be evaluated to assess the feasibility of substituting LPG import with the domestic coal-based DME and state budget saving that can be obtained from the substitution.

\subsection{DME Distribution Scheme}

The DME distribution scheme follows the existing LPG distribution scheme. This can be applied because they have the same characteristics. Moreover, LPG has a higher saturated vapor pressure than DME so the equipment designed for LPG can also be used for DME.

The DME distribution scheme analysed in this study is limited to the shipment from the DME plant in East
Kalimantan to the depots, as described by the figure below.

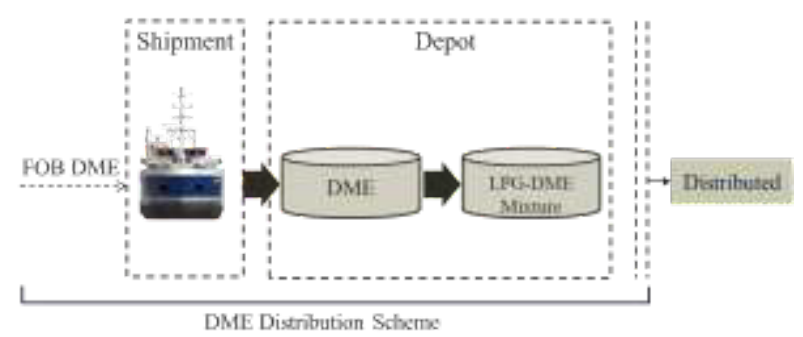

Fig. 1. DME Distribution Scheme from DME Plant to Depots

This scheme is applied for DME distribution from DME plant to each depots. Based on the previous study [7], the selected depots in this study are depots which regularly receive imported LPG and already have blending facilities to mix propane and butane. Those depots are Tanjung Priok Depot, Eretan Depot, Tanjung Perak Depot, Gresik Depot, and Semarang Depot.

\section{Economic Analysis for DME-LPG Mixture for Household Sector}

\subsection{Coal-based DME FOB Price Calculation}

The coal-based DME FOB price referred to the previous study based on the methodology used by Phillips et al (2007) with minimum selling fuel price (MSFP) at 10\% IRR [1]. In this study, coal-based DME plant is assumed to be located in East Kalimantan closed to the location of coal sources as the raw material. The calculation components of the coal-based DME FOB price are total investment cost (CAPEX), raw material efficiency, utility cost, raw material price, and electricity selling price as a DME plant by-product.

CAPEX calculation of DME plant based on direct synthesis process (direct DME synthesis) used in NKK corp. Japan (2003) for plant capacity 2,500 MT/day required CAPEX 480 million USD. As to know the current price due to price escalation, the correction of price in 2003 with price index of Chemical Engineering Plant Cost Index (CEPCI) calculated using equation (1) as follows:

$$
E x=E y \frac{N x}{N y}
$$

where,
Ex : Price Year X
Ey : Price Year Y
$\mathrm{Nx}$ : Price Index Year X
Ny : Price Index Year Y

and the result obtained from this equation is as shown in Table 3 . 
Table 3. DME Plant CAPEX Estimation Year 2017

\begin{tabular}{|c|c|c|c|}
\hline $\begin{array}{c}\text { Plant } \\
\text { Capacity } \\
\text { (MT/day) }\end{array}$ & Year & Index & $\begin{array}{c}\text { CAPEX } \\
\text { (million USD) }\end{array}$ \\
\hline 2,500 & 2003 & 402 & 480 \\
\hline 8,700 & 2017 & 574 & 1,448 \\
\hline
\end{tabular}

From the table it is known that the DME plant with capacity of 8,700 MT/day in 2017 has CAPEX 1,448 million USD.

Another parameter for the FOB DME price is the efficiency of the feedstock. The efficiency of raw materials shows how much the coal needed to produce DME, where efficiency will depend on the thermal efficiency of a process or known as cold gas efficiency. Referring to CCUJ (Central for Coal Utilization) and JIE (Japan Institute Energy), DME production from coal has an efficiency $60 \%$ or $46 \mathrm{MMBTU} / \mathrm{MT}$ DME. Besides, utility costs such as water, electricity and other costs required in producing DME also affect the FOB DME price. Utility costs will depend on the type of DME synthesis process. For DME production process according to CCUJ data (2003) is 5.3 USD/MT DME. Using equation (1) due to the price correction of 2003 to 2017 obtained 7.6 USD/MT DME.

The coal price as raw material also affects the price of coal-based DME FOB price. Raw material price refers to Coal Reference Price (Harga Batubara Acuan) for December 2017 is $94.04 \mathrm{USD} / \mathrm{MT}$ [5] or equivalent to 4.65 USD / MMBTU with the assumption that 1 ton of coal is equivalent to $20,224,900$ BTU. Meanwhile, the sale of electricity as a by-product of the DME plant is obtained due to the low gas efficiency of the coal gasification process only about $60 \%$. Therefore, the remaining heat released can be utilized to generate electricity through turbine gas. The assumptions used are thermal efficiency of turbine gas $35 \%$, heat rate 10,000 $\mathrm{BTU} / \mathrm{KWh}$, and capacity factor $75 \%$. The calculation uses the equation as follows.

$K W h=\frac{M f \times L H V \times \eta}{H R} \times C f$

where,

KWh : amount of KWh generated by Generator

Mf : amount of fuel (MT)

LHV : lower heating value $(\mathrm{Kcal} / \mathrm{Kg})$

HR : heat rate (BTU/KWh)

$\eta \quad$ : thermal efficience (\%)

Cf : capacity factor $(\%)$

by using equation (2) the result obtained that the amount of power generated from the DME production process from coal is $483 \mathrm{KWh} / \mathrm{MT}$ DME.

The data and assumptions used to calculate the FOB DME price are as shown in Table 4.
Table 4. Data and Assumptions for DME FOB Price Calculation

\begin{tabular}{|c|c|c|}
\hline No. & \multicolumn{2}{|c|}{ Data and Assumptions } \\
\hline 1 & Project Lifetime & 20 years \\
\hline 2 & Construction Phase & \\
\hline & - Phase 1 & $25 \%$ \\
\hline & - Phase 2 & $35 \%$ \\
\hline & - Phase 3 & $40 \%$ \\
\hline 3 & Operation in A Year & 333 days \\
\hline 4 & Interest Rate Loan & $12 \%$ \\
\hline 5 & Income Tax & $30 \%$ \\
\hline 6 & Discount Factor & $10 \%$ \\
\hline 7 & \% Weight DME & $15 \%$ \\
\hline 8 & Scale Factor & $60 \%$ \\
\hline 9 & CEPCI 2017 & 574 \\
\hline 10 & CEPCI 2003 & 402 \\
\hline 11 & HHV DME & $6,900 \mathrm{Kcal} / \mathrm{Kg}$ \\
\hline 12 & HHV Coal & $5,100 \mathrm{Kcal} / \mathrm{Kg}$ \\
\hline 13 & Load Factor & \\
\hline & - Year $1^{\text {st }}$ & $90 \%$ \\
\hline & - Year $2^{\text {nd }}$ & $95 \%$ \\
\hline & - Year $3^{\text {rd }}$ & $100 \%$ \\
\hline 14 & Coal Price & $\begin{array}{c}4.65 \\
\text { USD/MMBTU }\end{array}$ \\
\hline 15 & Production Capacity & 8,700 MT/day \\
\hline 16 & CAPEX & 1,448 million USD \\
\hline 17 & OPEX & \\
\hline & - Raw Materials & $\begin{array}{c}46 \mathrm{MMBTU} / \text { ton } \\
\text { DME }\end{array}$ \\
\hline & - Utility Cost & $8 \mathrm{USD} /$ ton DME \\
\hline & - Electricity Production & $\begin{array}{c}480 \mathrm{KWh} / \text { ton } \\
\mathrm{DME}\end{array}$ \\
\hline & - Maintenance Cost & $3 \%$ CAPEX \\
\hline & - Administration Cost, etc. & $0.5 \%$ CAPEX \\
\hline
\end{tabular}

Based on these data and assumptions, using Discounted Cash Flow method, the coal-based DME FOB price at IRR $10 \%$ is 327 USD/MT.

\subsection{Shipping Fee Calculation}

Generally, the classification of vessel types used to transport refined products is based on the ability of vessel to sail through certain shipping lines and the maximum capacity of products that can be loaded in the vessel. One of the most common system in the world for vessel type classification is AFRA (Average Freight Rate Assessment). The classification is based on the deadweight tonnage of the vessel. Whereas, the vessels' maximum capacity can be calculated by $90 \%$ deadweight tonnage depending on the density of each product. AFRA Scale for ship classification is depicted in Figure 2. 


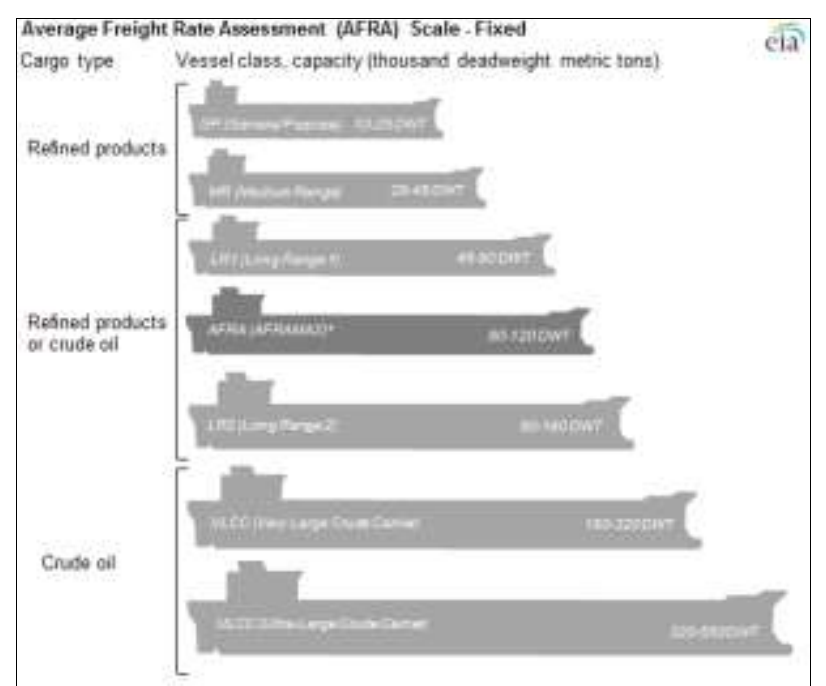

Fig. 2. AFRA Scale for Ship Classifications based on Load Capacity (deadweight metric tons)

source: https://www.eia.gov/todayinenergy/detail.php?id=17991

Based on the Figure 2, it can be seen that the vessel with the deadweight tonnage (dwt) below 25 dwt can be classified as small vessel with the maximum capacity up to $22.5 \mathrm{dwt}$. And the DME shipment from DME plant to the depots is sufficient with the small vessel.

Table 5. Shipping Fee Calculation from DME Plant to Each Depot Locations

\begin{tabular}{|c|c|c|c|c|c|}
\hline Description & $\mathbf{A}$ & B & $\mathbf{C}$ & D & $\mathbf{E}$ \\
\hline $\begin{array}{l}\text { Vessel Speed } \\
\text { (nm/hour) }\end{array}$ & 11 & 11 & 11 & 11 & 11 \\
\hline $\begin{array}{l}\text { Depot Throughput } \\
\text { (MT/day) }\end{array}$ & 1,676 & 1,822 & 874 & 801 & 583 \\
\hline Distance $(\mathrm{nm})$ & 943 & 769 & 534 & 594 & 792 \\
\hline Voyage (day) & 3.57 & 2.91 & 2.02 & 2.25 & 3 \\
\hline \multicolumn{6}{|c|}{ Vessel Loading-Unloading: } \\
\hline - Docked (hour) & 3 & 3 & 3 & 3 & 3 \\
\hline $\begin{array}{l}\text { - Connecting Hosts } \\
\text { (hour) }\end{array}$ & 0.5 & 0.5 & 0.5 & 0.5 & 0.5 \\
\hline $\begin{array}{l}\text { - Cargo Calculation } \\
\text { (hour) }\end{array}$ & 2 & 2 & 2 & 2 & 2 \\
\hline $\begin{array}{l}\text { - Cargo Pumping } \\
\text { (hour) }\end{array}$ & 12.78 & 13.89 & 6.67 & 6.11 & 4.44 \\
\hline $\begin{array}{l}\text { - Disconnecting } \\
\text { Hosts (hour) }\end{array}$ & 0.5 & 0.5 & 0.5 & 0.5 & 0.5 \\
\hline $\begin{array}{l}\text { - Cargo \& Ship } \\
\begin{array}{l}\text { Documentation } \\
\text { (hour) }\end{array}\end{array}$ & 2 & 2 & 2 & 2 & 2 \\
\hline $\begin{array}{l}\text { - ATD (Actual } \\
\text { Time Departure) } \\
\text { (hour) }\end{array}$ & 0.5 & 0.5 & 0.5 & 0.5 & 0.5 \\
\hline $\begin{array}{l}\text { - Berthing- } \\
\text { Unberthing (hour) }\end{array}$ & 1 & 1 & 1 & 1 & 1 \\
\hline $\begin{array}{l}\text { RTD (Roundtrip } \\
\text { Days) }\end{array}$ & 9 & 7 & 6 & 6 & 7 \\
\hline $\begin{array}{l}\text { Shipping Fee } \\
\text { (USD/MT) }\end{array}$ & 12.68 & 12.18 & 16.50 & 16.96 & 19.41 \\
\hline
\end{tabular}

Note:

A : Depot Tanjung Priok

B : Depot Eretan

C : Depot Tanjung Perak

D : Depot Gresik

E : Depot Semarang
The shipping fee is calculated from the cost needed to transport DME from the plant to the location of each depots. Those depots are Tanjung Priok Depot, Eretan Depot, Tanjung Perak Depot, Gresik Depot, and Semarang Depot. The location of the DME plant is assumed in East Kalimantan closed to the source of coal as raw material. The shipping fee is calculated by the discounted cash flow method to get the minimum IRR $15 \%$, and the result is as shown in Table 5 .

According to the Table 5, the roundtrip days (RTD) of each vessels are the time takes to sail back and forth to the plant site and depot. Based on the RTD, the vessel rent cost to accommodate the throughput of each depot that should be transported by vessel in every metric ton (MT) of cargo is considered as a shipping fee. The result of shipping fee for each depots are 12.68 USD/MT Tanjung Priok Depot, 12.18 USD/MT Eretan Depot, 16.50 USD/MT Tanjung Perak Depot, 16.96 USD/MT Gresik Depot, and 19.41 USD/MT Semarang Depot.

\subsection{Depot Fee Calculation}

Currently, the imported LPG received at the depot in the existing distribution scheme are propane and butane, then they are blended at the depot. The price of imported LPG at depot then will be compared with the DME-LPG mixture price at depot. Besides coal-based DME FOB price, and shipping fee, another component in DMELPG mixture price is depot fee. There are several parameters to calculate the depot fee, such as investment cost (CAPEX) and operating cost (OPEX) at the selected depots. The selected depots are depots that already have propane and butane blending facilities therefore the required CAPEX is only for the additional DME storage facilities.

The additional DME storage tank capacity in each depot can be calculated based on DME demand in 2040 and vessel RTD in distributing DME to each depots. The existing and additional DME storage capacities are as shown in Table 6.

Table 6. Existing Storage Facilities \& Proposed Storage Facilities

\begin{tabular}{|c|c|c|}
\hline Depot & Existing & Proposed \\
\hline \multirow{4}{*}{ Tanjung Priok } & \multicolumn{2}{|c|}{ Capacity (MT) } \\
\hline & $2 \times 500$ & \multirow{3}{*}{$8 \times 2,500$} \\
\hline & $2 \times 750$ & \\
\hline & $4 \times 1,500$ & \\
\hline Total Capacity (MT) & 8,500 & 20,000 \\
\hline \multirow{2}{*}{ Eretan } & \multirow{2}{*}{$4 \times 2,500$} & $7 \times 2,500$ \\
\hline & & $2 \times 2,000$ \\
\hline Total Capacity (MT) & 10,000 & 21,500 \\
\hline \multirow{3}{*}{ Tanjung Perak } & $4 \times 1,500$ & $3 \times 2,500$ \\
\hline & $2 \times 750$ & \multirow{2}{*}{$2 \times 1,500$} \\
\hline & $2 \times 750$ & \\
\hline Total Capacity (MT) & 8,000 & 10,500 \\
\hline Depot & Existing & Proposed \\
\hline \multirow{2}{*}{ Gresik } & \multirow{2}{*}{$4 \times 2,500$} & $3 \times 2,500$ \\
\hline & & $2 \times 1,000$ \\
\hline Total Capacity (MT) & 10,000 & 9,500 \\
\hline \multirow{2}{*}{ Semarang } & \multirow{2}{*}{$4 \times 2,500$} & $2 \times 2,500$ \\
\hline & & $2 \times 1,000$ \\
\hline Total Capacity (MT) & 10,000 & 7,000 \\
\hline
\end{tabular}


Based on the reference from Lemigas research [8], detailed assumptions and data in economic calculation are as shown in Table 7.

Table 7. Data and Assumptions for Depot Fee Calculation

\begin{tabular}{|c|l|c|}
\hline No. & \multicolumn{2}{|c|}{ Data \& Assumptions } \\
\hline 1 & Project Lifetime & 20 Years \\
\hline 2 & Operation in A Year & 330 Days \\
\hline 3 & Loan Period & 3 Years \\
\hline 4 & Interest Rate Loan & $12 \%$ \\
\hline 5 & Investment Portion: & \\
\hline & - Internal Equity & $30 \%$ \\
\hline & - Bank Loan & $70 \%$ \\
\hline 6 & Income Tax & $25 \%$ \\
\hline 7 & Discount Factor & $10 \%$ \\
\hline 8 & Scale Factor & $60 \%$ \\
\hline 9 & Exchange Rate of & IDR 13,740/ \\
& USD - IDR & 1 USD \\
\hline 10 & Investment Reference: & 2,000 Ton \\
\hline & - Capacity & USD 6,231,004 \\
\hline & - CAPEX (2018) \\
\hline
\end{tabular}

Meanwhile, the operating and maintenance costs assumption used 5\% CAPEX, and insurance costs 3\% CAPEX. The depot fee is calculated by the discounted cash flow method to get the minimum IRR $15 \%$, and the result is as shown in Table 8 .

Table 8. Depot Fee Calculation

\begin{tabular}{|c|c|c|c|c|c|c|}
\hline No. & Description & $\mathbf{A}$ & B & $\mathrm{C}$ & D & $\mathbf{E}$ \\
\hline 1 & $\begin{array}{l}\text { Total Storage } \\
\text { Capacity } \\
\text { (thousand MT) }\end{array}$ & 20 & 21.5 & 10.5 & 9.5 & 7 \\
\hline 2 & $\begin{array}{l}\text { CAPEX } \\
\text { (million USD) }\end{array}$ & 56.99 & 62.33 & 31.86 & 29.59 & 22.47 \\
\hline 3 & $\begin{array}{l}\text { Operation \& } \\
\text { Maintenance } \\
\text { Cost (million } \\
\text { USD) }\end{array}$ & 2.85 & 3.12 & 1.59 & 1.48 & 1.12 \\
\hline 4 & $\begin{array}{l}\text { Inssurance } \\
\text { Cost (million } \\
\text { USD) }\end{array}$ & 1.71 & 1.87 & 0.96 & 0.89 & 0.67 \\
\hline 5 & $\begin{array}{l}\text { OPEX } \\
\text { Escalation } \\
\text { (million USD) } \\
\end{array}$ & $5 \%$ & $5 \%$ & $5 \%$ & $5 \%$ & $5 \%$ \\
\hline 6 & $\begin{array}{l}\text { Depot Fee } \\
\text { (USD/MT) }\end{array}$ & 28.64 & 28.83 & 30.68 & 31.07 & 32.46 \\
\hline
\end{tabular}

According to the table, the depot fees at each depots are 28.64 USD/MT at Depot Tanjung Priok, 28.83 USD/MT at Depot Eretan, 30.68 USD/MT at Depot Tanjung Perak, 31.07 USD/MT at Depot Gresik, and 32.46 USD/MT at Depot Semarang.

\section{State Budget Saving}

The state budget saving is calculated by comparing the price between DME-LPG mixture and the LPG import at depot. The DME-LPG mixture price is generated from domestic coal utilization to be processed into DME to fulfil the household sector demand in 2040. Meanwhile the LPG import price depends on the propane and butane price at the delivery point (depot) in Indonesia. The DME-LPG mixture price consists of coal-based DME FOB price, shipping fee from the DME plant to each depots, depot fee for DME handling, and the current LPG depot handling fee. Currently, LPG depot fee is 300 IDR/MT or equivalent to $21.83 \mathrm{USD} / \mathrm{MT}$. The calculation components of LPG import price at the depot as the delivery point are as shown in Table 9.

Table 9. Component of LPG Import Price Calculation at Depot LPG

\begin{tabular}{|l|c|l|}
\hline \multicolumn{1}{|c|}{ Calculation Factors } & \multicolumn{2}{c|}{ Value } \\
\hline Propane Price $(\alpha)$ & 525 & USD/MT \\
\hline Butane Price $(\beta)$ & 505 & USD/MT \\
\hline Propane Composition $(\mathrm{X})$ & $42 \%$ & x Propane Price \\
\hline Butane Composition $(\mathrm{Y})$ & $58 \%$ & x Butane Price \\
\hline $\begin{array}{l}\text { Contract Price }(\mathrm{CP}) \\
\text { Aramco }\end{array}$ & 513 & $\mathrm{USD} / \mathrm{MT}$ \\
\hline Freight Cost & 68.64 & $\mathrm{USD} / \mathrm{MT}$ \\
\hline Import Constant & $1.88 \%$ & x CP Aramco \\
\hline
\end{tabular}

Components of the calculation if expressed in the equation are as follows.

$\mathrm{CP}$ Aramco $=(\mathrm{X} \times \alpha)+(\mathrm{Y} \times \beta)$

Having obtained the value of CP Aramco, the value goes into the following equation.

$$
\begin{aligned}
\text { LPG Import Price }= & \text { CP Aramco x }(1+\text { Import Constant }) \\
& + \text { Freight Cost } \quad \ldots \text { Eq. }(4)
\end{aligned}
$$

Obtained from the calculation that the LPG import price is $591 \mathrm{USD} / \mathrm{MT}$, and LPG import price at Depot will include theexisting LPG handling fee 21,83 USD/MT therefore the total LPG import price at each depots are $620 \mathrm{USD} / \mathrm{MT}$ at Depot Tanjung Priok, $620 \mathrm{USD} / \mathrm{MT}$ at Depot Eretan, 622 USD/MT at Depot Tanjung Perak, 622 USD/MT at Depot Gresik, 624 USD/MT Depot Semarang. This price becomes the reference to calculate the state budget saving compare with the economic price of DME-LPG mixture at depot. While the price of DMELPG mixtures in each depots will depend on the distance of depot location from the DME plant that affects the number of additional DME storage tank facilities required. The comparison between LPG import and the DME-LPG mixture price at each depot are as shown in Table 10. 
Table 10. Benefit Reduction of APBN Year 2040 from Each Depot

\begin{tabular}{|l|c|c|c|c|c|c|}
\hline Description & Unit & A & B & C & D & E \\
\hline $\begin{array}{l}\text { DME FOB } \\
\text { Price }\end{array}$ & USD/MT & \multicolumn{5}{|c|}{327} \\
\hline $\begin{array}{l}\text { Shipping } \\
\text { Fee }\end{array}$ & USD/MT & 12.68 & 12.18 & 16.50 & 16.96 & 19.41 \\
\hline Depot Fee & USD/MT & 28.64 & 28.83 & 30.68 & 31.07 & 32.46 \\
\hline $\begin{array}{l}\text { Depot LPG } \\
\text { Fee }\end{array}$ & USD/MT & \multicolumn{5}{|c|}{21.83} \\
\hline $\begin{array}{l}\text { DME-LPG } \\
\text { Mixture } \\
\text { Price }\end{array}$ & USD/MT & 391 & 390 & 396 & 397 & 401 \\
\hline $\begin{array}{l}\text { LPG Import } \\
\text { Price }\end{array}$ & USD/MT & 591 & 591 & 591 & 591 & 591 \\
\hline $\begin{array}{l}\text { Depot LPG } \\
\text { Fee }\end{array}$ & USD/MT & & \multicolumn{5}{|c|}{21.83} \\
\hline $\begin{array}{l}\text { LPG Import } \\
\text { Price at } \\
\text { Depot }\end{array}$ & USD/MT & 620 & 620 & 622 & 622 & 624 \\
\hline Saving & USD/MT & 251 & 223 & 217 & 216 & 212 \\
\hline $\begin{array}{l}\text { APBN } \\
\text { Saving } \\
\text { Year 2040 }\end{array}$ & $\begin{array}{l}\text { Million } \\
\text { USD/Year }\end{array}$ & $\mathbf{1 2 3}$ & $\mathbf{1 2 1}$ & $\mathbf{5 6}$ & $\mathbf{5 1}$ & $\mathbf{3 7}$ \\
\hline
\end{tabular}

According to the table above, the comparison between LPG import price and DME-LPG mixture price result the state budget saving at Depot Tanjung Priok 123 million USD per year, at Depot Eretan 121 million USD per year, at Depot Tanjung Perak 56 million USD per year, at Depot Gresik 51 million USD per year, and at Depot Semarang 37 million USD per year. The total state budget saving can be seen in the Table 11 below.

Table 11. Total State Budget Saving in 2040

\begin{tabular}{|c|c|c|}
\hline \multirow{2}{*}{$\begin{array}{c}\text { APBN Saving } \\
\text { Year 2040 }\end{array}$} & \multicolumn{2}{|c|}{ Value } \\
\cline { 2 - 3 } & 5,332 & Billion IDR/Year \\
\cline { 2 - 3 } & 388 & Million USD/Year \\
\hline
\end{tabular}

Based on the table above can be concluded that the utilization of coal-based DME to substitute LPG import in Indonesia can give total state budget saving for the government about 5,332 billion Rupiahs per year or equal to 388 million USD per year.

\section{Sensitivity Analysis}

\subsection{Coal Price vs DME-LPG Mixture Price}

The sensitivity analysis of coal price towards the DMELPG mixture price will be evaluated by the change of coal price. There are 3 (three) variances of coal price, 94.04 USD/MT or equivalent to $4.65 \mathrm{USD} / \mathrm{mmbtu}$ (HBA December 2017), increasing up to $15 \%$ and decreasing up to $15 \%$ (the range of price change based on the historical data) and the result is as shown in Table 12 .

It can be inferred from the tables that the increase of coal price $15 \%$ or equal to $108 \mathrm{USD} / \mathrm{MT}$ resulted the DME-LPG mixture price increasing 32 USD/MT. Meanwhile, the decrease $15 \%$ resulted the DME-LPG mixture price decreasing $32 \mathrm{USD} / \mathrm{MT}$. Therefore, it can be concluded that by the change $1 \%$ of coal price will affect the change of DME-LPG mixture price 2.1 $\mathrm{USD} / \mathrm{MT}$.

Table 12. Sensitivity Analysis of Coal Price vs DME-LPG Mixture Price

\begin{tabular}{|c|c|c|c|c|c|}
\hline $\begin{array}{c}\text { Coal Price } \\
\text { (USD/mmbtu) }\end{array}$ & \multicolumn{5}{|c|}{$\begin{array}{c}\text { DME-LPG Mixture Price } \\
\text { (USD/MT) }\end{array}$} \\
\hline & A & B & C & D & E \\
\hline 3,95 & 359 & 358 & 364 & 365 & 369 \\
\hline 4,65 & 391 & 390 & 396 & 397 & 401 \\
\hline 5,11 & 423 & 422 & 429 & 429 & 433 \\
\hline
\end{tabular}

\subsection{CAPEX vs DME-LPG Mixture Price}

The sensitivity analysis of CAPEX DME Storage towards the DME-LPG mixture price at each depots will be evaluated by changing the investment cost in 2 (two) variances, plus $25 \%$ and $50 \%$. The result is as shown in Table 13.

Table 13. Sensitivity Analysis of CAPEX vs DME-LPG Mixture Price

\begin{tabular}{|c|c|c|c|c|c|c|}
\hline \multirow{3}{*}{ Depot } & \multicolumn{2}{|c|}{ CAPEX (Initial) } & \multicolumn{2}{c|}{ CAPEX 1 (+25\%) } & \multicolumn{2}{c|}{ CAPEX 2 (+50\%) } \\
\cline { 2 - 7 } & $\begin{array}{c}\text { CAPEX } \\
\text { Million } \\
\text { (USD) }\end{array}$ & $\begin{array}{c}\text { DME- } \\
\text { LPG } \\
\text { Mixture } \\
\text { Price } \\
\text { (USD/MT) }\end{array}$ & $\begin{array}{c}\text { CAPEX } \\
\text { Million } \\
\text { (USD) }\end{array}$ & $\begin{array}{c}\text { DME- } \\
\text { LPG } \\
\text { Mixture } \\
\text { Price } \\
\text { (USD/MT) }\end{array}$ & $\begin{array}{c}\text { CAPEX } \\
\text { Million } \\
\text { (USD) }\end{array}$ & $\begin{array}{c}\text { DME-LPG } \\
\text { Mixture } \\
\text { Price } \\
\text { (USD/MT) }\end{array}$ \\
\hline $\mathrm{A}$ & 56,99 & 391 & 71,24 & 396 & 85,48 & 405 \\
\hline $\mathrm{B}$ & 62,33 & 390 & 77,91 & 395 & 93,49 & 405 \\
\hline $\mathrm{C}$ & 31,86 & 396 & 39,82 & 402 & 47,79 & 412 \\
\hline $\mathrm{D}$ & 29,59 & 397 & 36,99 & 403 & 44,39 & 413 \\
\hline $\mathrm{E}$ & 22,47 & 401 & 28,09 & 407 & 33,70 & 417 \\
\hline
\end{tabular}

Based on the calculation, the increase of investment cost $25 \%$ and $50 \%$ resulted the increase of DME-LPG mixture price 9-11 USD/MT. It can be concluded, by the change $1 \%$ of CAPEX DME storage at each depot will affect the change of DME-LPG mixture price $0.37-0.42$ USD/MT.

\subsection{IRR vs DME-LPG Mixture Price}

The sensitivity analysis of IRR towards the DME-LPG mixture price at each depots will be evaluated by changing the IRR in 2 (two) variances, plus $10 \%$ and $20 \%$. The result is as shown in Table 14 .

Table 14. Sensitivity Analysis of IRR vs DME-LPG Mixture Price

\begin{tabular}{|c|c|c|c|c|c|}
\hline \multirow{2}{*}{ IRR } & \multicolumn{5}{|c|}{$\begin{array}{c}\text { DME-LPG Mixture Price } \\
\text { (USD/MT) }\end{array}$} \\
\cline { 2 - 6 } & $\mathbf{A}$ & $\mathbf{B}$ & $\mathbf{C}$ & $\mathbf{D}$ & $\mathbf{E}$ \\
\hline $10 \%$ & 386 & 385 & 391 & 392 & 396 \\
\hline $15 \%$ & 391 & 390 & 396 & 397 & 401 \\
\hline $20 \%$ & 396 & 395 & 402 & 403 & 407 \\
\hline
\end{tabular}

According to the calculation for IRR $10 \%$ and $20 \%$, the increase of DME-LPG mixture price is 5-6 USD/MT. It can be concluded, by the change $1 \%$ of IRR will affect the change of DME-LPG mixture price 1.1-1.2 USD/MT. 


\subsection{Sensitivity Analysis of Parameters Change towards The State Budget Saving}

Based on the previous sub-section about the sensitivity analysis of some parameters towards the DME-LPG mixture price, in this section we would analysis those parameters' impact to the state budget saving for the DME demand in 2040. The parameters change is calculated per $1 \%$, it means that $1 \%$ change of parameters will affect the increase or decrease of state budget in USD/year. The result of simulation is as shown in Table 15.

Table 15. Sensitivity Analysis of IRR vs DME-LPG Mixture Price

\begin{tabular}{|l|c|c|}
\hline $\begin{array}{l}\text { per 1\% changing to } \\
\text { these parameters: }\end{array}$ & $\begin{array}{c}\text { DME-LPG } \\
\text { Mixture } \\
\text { Price } \\
\text { (USD/MT) }\end{array}$ & $\begin{array}{c}\text { State Budget } \\
\text { Saving } \\
\text { Increase/Decrease } \\
\text { (USD/Year) }\end{array}$ \\
\hline Coal Price $\uparrow \downarrow$ & 2.1 & $3,988,965$ \\
\hline $\begin{array}{l}\text { CAPEX DME } \\
\text { Storage } \uparrow \downarrow\end{array}$ & 0.37 & 702,818 \\
\hline \multirow{2}{*}{ IRR Depot Fee $\uparrow \downarrow$} & 0.42 & 797,793 \\
\cline { 2 - 3 } & 1.1 & $2,089,458$ \\
\hline
\end{tabular}

According to the table above, the coal price changes 1\% resulted the increase or decrease state budget saving $3,988,965$ USD/year. And the CAPEX DME storage changes $1 \%$ resulted the increase or decrease state budget saving $702,818 \mathrm{USD} /$ year up to $797,793 \mathrm{USD} /$ year. Meanwhile, the IRR depot fee changes $1 \%$ resulted the increase or decrease state budget saving 2,089,458 USD/year up to $2,279,408$ USD/year. Figure 3 illustrates the sensitivity of those parameters toward the state budget saving.

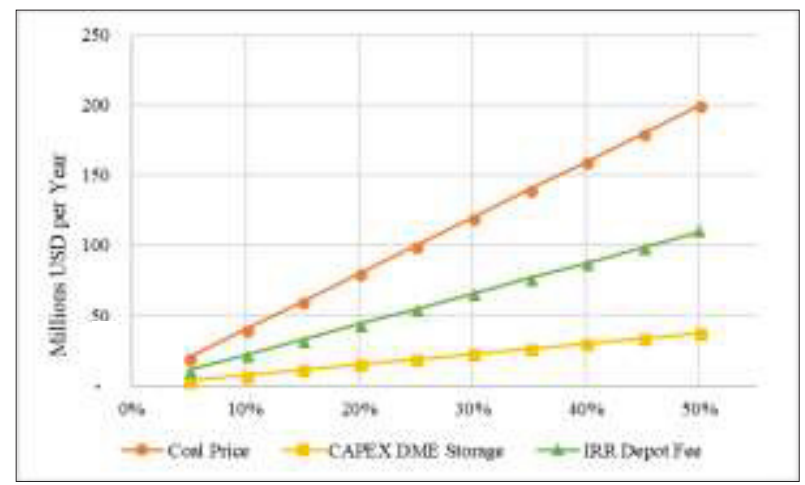

Fig. 3. Sensitivity Analysis of Parameters Change per Percentage towards The State Budget Saving in 2040

It can be concluded that the change of Coal Price will dominantly affect the state budget saving, then the second is IRR for Depot Fee calculation and the lowest impact to the state budget saving is the change of CAPEX DME Storage at depot.

The authors acknowledge Universitas Indonesia and PITTA 2018 program for the financial support. We also thank PPPTMGB LEMIGAS for the support to provide data.

\section{References}

1. Aulia, M. R. (2015). Keekonomian Dimetil Eter sebagai Substitusi Impor LPG pada Industri Rumah Tangga. Indonesia: Universitas Indonesia.

2. Djuningsih, F. (2016). Keekonomian Pemanfaatan Dimetil Eter sebagai Bahan Bakar Pencampur LPG di Sektor Rumah Tangga di Indonesia Melalui Kebijakan Mandatori Pemerintah. Indonesia: Universitas Indonesia.

3. Fleisch, T.H., A. Basu \& R.A. Sills. Introduction and advancement of a new clean global fuel: The status of DME developments in China and beyond. Journal of Natural Gas Science and Engineering 9:94-107 (2012).

4. IEA. (2017). Coal Information Overview. Indonesia: International Energy Agency.

5. KESDM. (2017). Handbook of Energy and Economic Statistics of Indonesia. Jakarta: Ministry of ESDM.

6. Pemerintah RI. (2013). Keputusan Dirjen Migas No.990.K/10/DJM.S/2013 tentang Standar dan Mutu (Spesifikasi) Bahan Bakar Gas Jenis Dimetil Eter untuk Rumah Tangga dan Industri yang Dipasarkan di Dalam Negeri. Indonesia: Dirjen Migas.

7. PPPTMGB LEMIGAS. (2016). Analisa Pola Rantai Suplai Pada Kelayakan Dimethyl Ether (DME). Jakarta.

8. Setjen DEN. (2016). Outlook Energi Indonesia 2016. Jakarta: Sekretariat Jenderal Dewan Energi Nasional. 